\title{
Identification of National Road Maintenance Needs based on Strategic Plan of Directorate General of Bina Marga (2015-2019)
}

\author{
Rizky Ardhiarini \\ National Road Implementing Agency III, Directorate General Bina Marga, Palembang, INDONESIA \\ rizky.ardhiarini@gmail.com
}

\begin{abstract}
The enhancement of connectivity between the main corridors of the economy in South Sumatera, as a purpose of the Strategic Plan of Directorate General Bina Marga and also an objective of MP3EI, Master Plan for Acceleration and Expansion of Indonesia's Economic Development which is an ambitious plan by the Indonesian government to accelerate the realization of becoming a developed country would be able to achieve on the requirement of good condition on performance and pavement. In order to support the optimal condition of the road, the identification of road management was conducted to determine the necessity of road maintenance based on technical conditions and importance level of development of the road traversed. The management program proposed is expected to be used as a baseline in determining the maintenance of the road network in South Sumatera from 2015 until 2019. This research used Multi-criteria Analysis (MCA) method, which consists of: (1) road network performance, covering width of roadways, traffic flow, V/C ratio, travel speed and travel time of the vehicle, and (2) pavement condition, with IRI, SDI, and the proportion of good pavement condition as a parameter. Multi-criteria analysis used combined road condition assessment score and importance level of development of the area traversed by. This analysis was conducted from 2015 until 2019. The research concluded that maintenance necessity in 2015 were dominated by routine maintenance (95.86\% of the total length), then in 2016 until 2019 the needs were dominated by routine maintenance (near $100 \%$ of the total length). As the maintenance applied, a vast amount of total road length fulfilled as an achievement target. The results are follows: (a) 100\% with width of roadways $\geq 7$ meter, (b) $97.83 \%$ with $\mathrm{V} / \mathrm{C}$ ratio $\langle 0.75$, (c) $18.50 \%$ with travel speed $>$ $60 \mathrm{~km} /$ hour, (d) $17.32 \%$ with travel time (TT) $<1.6$ hour $/ 100 \mathrm{~km}$, (e) $100 \%$ with good pavement condition $>95 \%$, (f) $90.37 \%$ with IRI $<4 \mathrm{~m} / \mathrm{Km}$, and (g) 91.59 with SDI $<50$. Yet with the achievement of $100 \%$ of total road length with a minimum width 7.0 meter, and $90.37 \%$ of total road length with an IRI less than $4.0 \mathrm{~m} / \mathrm{km}$ in 2019 , the impact was not significant on increasing length of the road with a travel time (TT) less than 1.6 hour/100km. The condition is caused by there are no maintenance requirements concerning the improvement of the substandard road geometric.
\end{abstract}

Keywords: road, necessity, management, suggestion

\section{INTRODUCTION}

The Republic of Indonesia Laws No. 38 of 2004 (Government of Indonesia, 2004) concerning Road mentioned that national road has important role in the region economy enhancement, therefore its service must be safe, secure, comfortable, and has effective and efficient budget. The road network management programming that Directorate General Bina Marga held to date is limited to reactive action on every year, so that it impressed a late handling, for the budget program for year $n$ is based on the existing condition of the same year (Koesno and Marbun, 1995; Sepang and Mouradhy, 1995; Pickford, 2013).

Based on the strategic program target (Directorate General of Bina Marga, 2014), the Directorate General Bina Marga needs to arrange a more comprehensive 2015-2019 medium-term program, by combining structural condition with road development priority of the area growth. This means that identification on national roads necessity is needed, based on the direction from Directorate General Bina Marga Strategic Plan of 2015-2019, thus it could be expected that it could be the management baseline of each year for the next 5 years. Directorate General Bina Marga must change the old paradigm of reactive approach to a more preventive approach, by creating a more rational anticipation program, particularly on the national road important traffics.

The objective of this research is to provide suggestion for the road management necessity program that combines structural technical condition of the road with the growth area interest level which the national road network traversed, in order to create an optimal, effective, and efficient road management program. 


\section{ROAD NETWORK CONNECTIVITY ENHANCEMENT EFFORT}

Directorate General Bina Marga Strategic Plan of 2015-2019 mentioned that one of the biggest challenges in creating road network connectivity is to achieve national road travel time of 1.0-2.0 hour per $100 \mathrm{~km}$ on 2019 (Ardhiarini, 2015). This means that the national road function as the primary arterial road that has travel speed of minimum $60 \mathrm{~km} /$ hour must be reverted, by minimizing disturbance in the right-ofway and the road usage space. The study result of (IndII, 2012) showed that travel time on the national road is 2.7 hour $/ \mathrm{km}$, which is far behind Vietnam (2.0 hour $/ \mathrm{km}$ ) and Malaysia (1.5 hours $/ \mathrm{km})$. Besides IndII, study result from (Mulyono, 2014) mentioned that travel time of the national road is 3.3 hour $/ 100 \mathrm{~km}$, particularly in the Indonesia east area, which was caused by the substandard road geometric. To achieve the existing national road travel time of 2.0 hour/100 $\mathrm{km}$, it needed several project activity, which is (1) increasing the capacity through road widening of minimum 7.0 meter, (2) structural increasing through adding the pavement thickness and damage repair, (3) periodical and routine maintenance.

\section{RESEARCH METHODS}

The research was conducted on the national road network which is located in South Sumatra Province on the National Road Implementation Agency III of Directorate General Bina Marga. The initial step on framing the national road management necessity program was conducted by doing inventory on the variables that affected the performance of the national road service. The variables were grouped into two categories, which are the technical condition category and the area interest level. Several of the significant variables in the technical condition category are: International Rough Index (IRI), Surface Distress Index (SDI), Average Daily Traffic (ADT), capacity, Volume Capacity Ratio (V/C ratio), travel speed, and travel time. Every variable could be rated based on the score condition of 1 (one) up to 6 (six), each showing the value of 1 (very poor), value of 2 (poor), value of 3 (fair), value of 4 (good), value of 5 (very good), and value of 6 (excellent). Several significant variables in the area interest level are National Activity Center National Strategic Area (Kawasan Strategis Nasional/Pusat Kegiatan Nasional-KSN/PKN) support, National Logistic Blueprint (Sistem Logistik Nasional-Sislognas), key region and resort area, economic corridor, regional road integration, National Tourism Strategic Area (Kawasan Strategis Pariwisata Nasional-KSPN), and also the protected area and the national park. Every variable could be rated based on the score condition of 1 (one) up to 4 (four), each showing the value of 1 (very important), value of 2 (important), value of 3 (less important), and value of 4 (not important). The next step was to conduct the multi-criteria analysis (MCA) between the score condition and rank of the area development which national road pass, as the input in transportation modeling, estimation for road stability, and estimation for road management program suggestion (DfCLG, 2009; Sulistyorini and Herianto, 2010; Maulidya, 2014). The suggestion for national road management program was adapted with the strategic program of Directorate General Bina Marga strategic plan of 2015-2019, as shown in Table 1. This research plot could be seen in Figure 1, which then conducted in accordance with the research steps, as seen in Figure 2.

Table 1. Program for national road network management (Directorate General of Bina Marga, 2014)

\begin{tabular}{llll}
\hline No. & Management Code & Management Program Type & Strategic Program Target \\
\hline 1 & A11 & inter-city road minor routine maintenance & inter-city national road asset \\
2 & A12 & inter-city road routine condition maintenance & program \\
3 & A13 & inter-city road routine preventive maintenance & \\
4 & A14 & inter-city road routine periodical maintenance & inter-city road modernization \\
5 & B11 & inter-city road major rehabilitation & \\
6 & B12 & road widening up to 7 meter (inter-city road) & \\
7 & B13 & road widening up to 14 meter (inter-city road) & \\
8 & B14 & city road minor routine maintenance & city national road asset management \\
9 & A21 & city road routine condition maintenance & \\
10 & A22 & city road routine preventive maintenance & \\
11 & A23 & city road routine periodical maintenance & city road modernization \\
12 & A24 & city road major rehabilitation & \\
13 & B21 & city road reconstruction & \\
14 & B22 & road widening up to 7 meter (city road) & \\
15 & B23 & road widening up to 14 meter (city road) & \\
16 & B24 & &
\end{tabular}




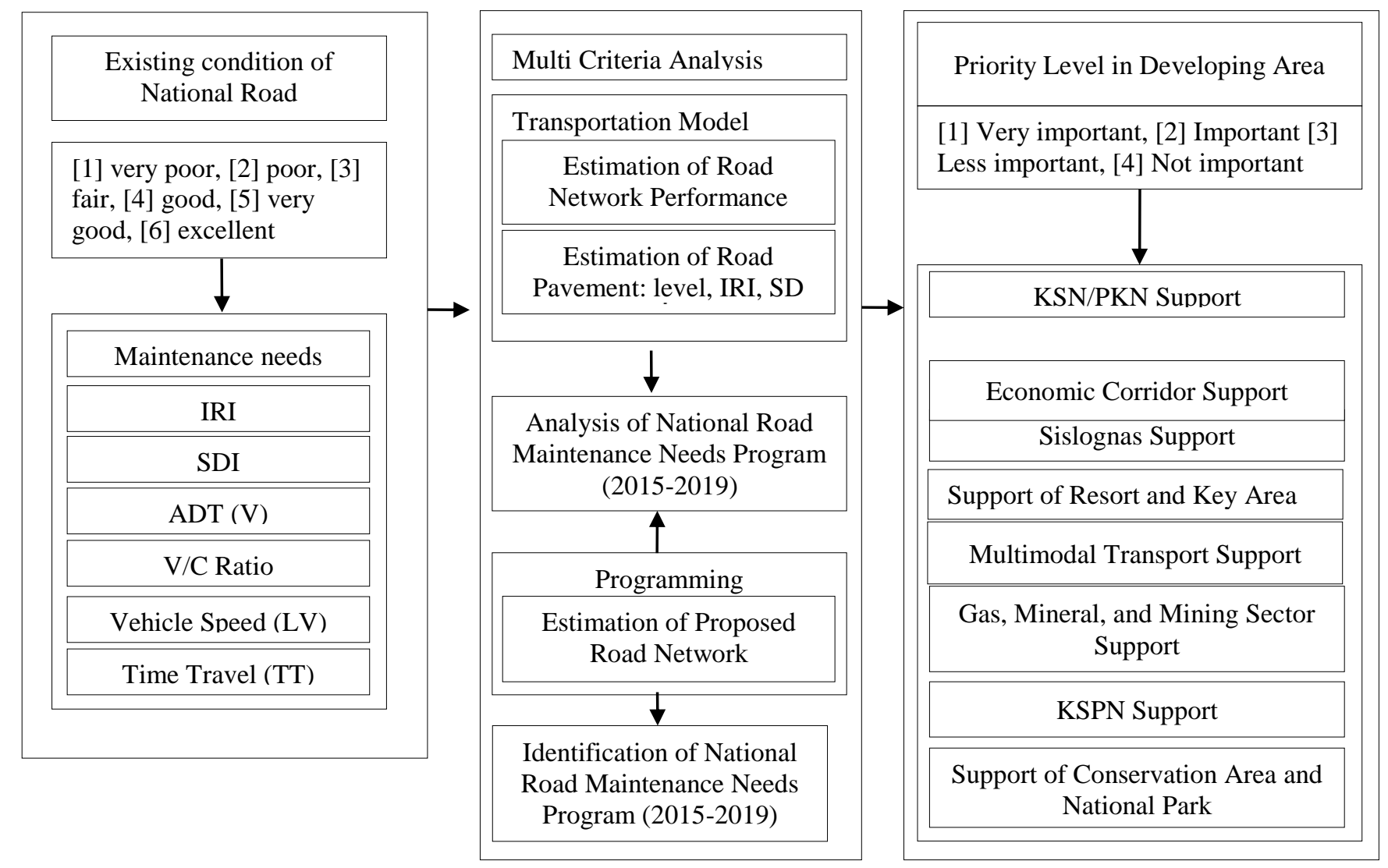

Figure 1. Plan of national road network estimation need

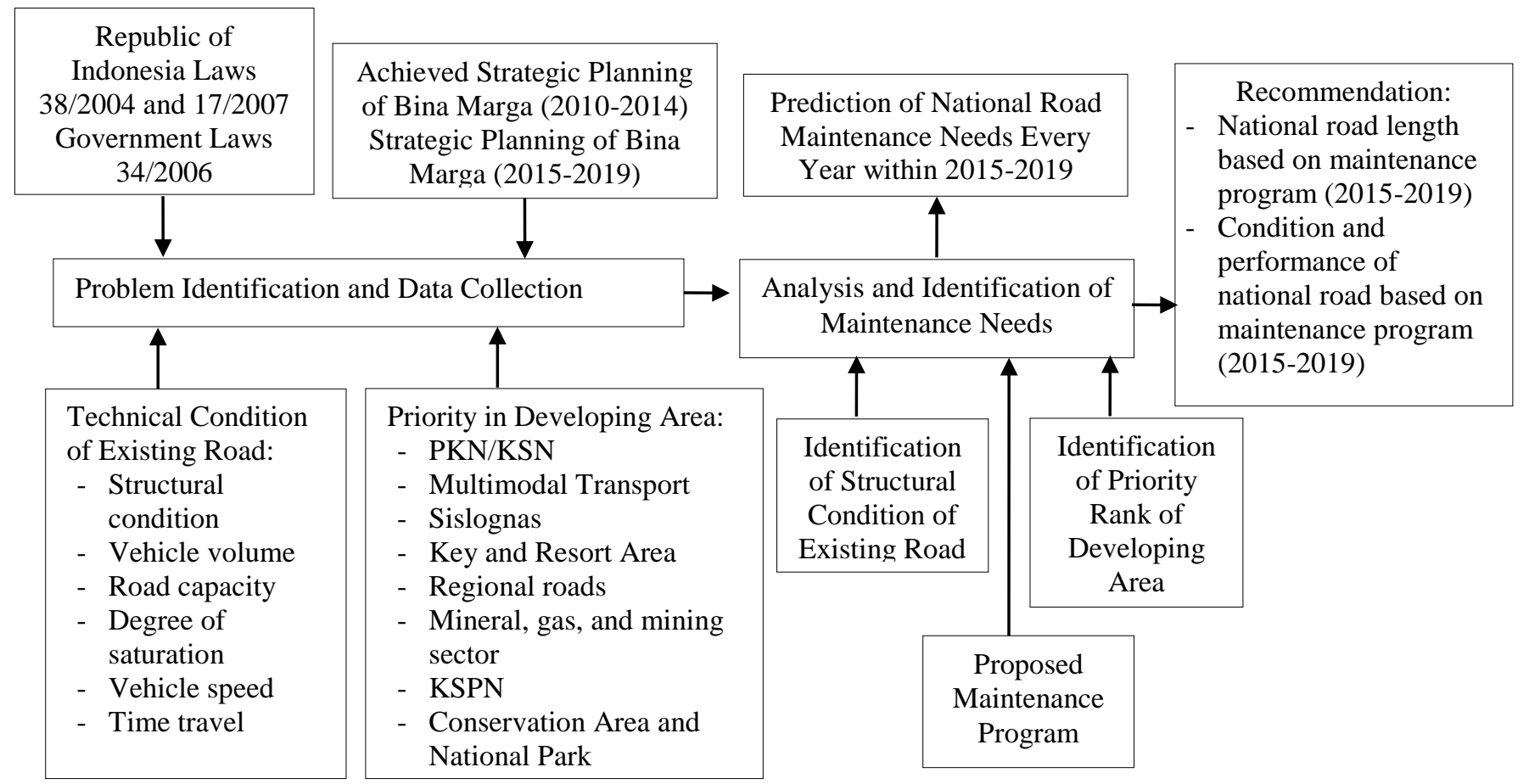

Figure 2. Research Steps. 


\section{ANALYSIS RESULT DISCUSSION}

\subsection{Initial Inventorying of Technical Condition and} Road Network Development Interest Level

The analysis result on the technical condition of the national road in the South Sumatra Province on 2015 was 4.11 (good) from the maximum scale of 6.00 . The technical condition value increases in the year 2016, 2017, and 2018 for each of 4.25, 4.27, and 4.28, then decreases in 2019 to 4.26 . The technical condition value indicates that the national road in the South Sumatra Province is in good category. The length total of national road significant traffic with smaller technical condition value from the national road condition total mean value in South Sumatra Province is shown in Table 2. Almost $20 \%$ of the lengths of east traffic and middle traffic on the national road have smaller technical condition value compared to technical condition total mean value. This means that $20 \%$ of the east traffic and middle traffic length is in bad condition.

The analysis result on area development interest level that is traversed by the national road in South Sumatra was 2.2 (important) from maximum scale of 4.00. Generally, the analysis result showed that the area development interest level that is traversed by the national road is smaller than the mean value of the area development interest level of the total national road network area. This means that generally the interest level of the national road network management in the South Sumatra was in an important category, as seen from the development interest of the South Sumatra area. Length of the national road that has lower area development interest rank than the mean rank of total national network was $798.57 \mathrm{~km}(55.29 \%)$ which consist of: (a) east traffic of $30.48 \%$ (440.16 km), (b) middle traffic of $13.12 \%$ $(189.44 \mathrm{~km})$, (c) connecting traffic of $11.70 \%$ (168.97 $\mathrm{km})$.

\subsection{Identification of National Road Network Management Necessity Suggestion}

The analysis result of road preservation necessity showed that the inter-city and city national road preservation program of South Sumatra in 2015-2019 were dominated by minor routine maintenance, routine condition maintenance, and routine preventive maintenance. This means that generally, the initial condition in each year is in goodcategory so that it would not need minor rehabilitation program, as seen in Figure 3 up to Figure 7.

The multi-criteria analysis that combined the rating score of technical structural road condition with the rank of area development interest level has resulted in an optimal, effective, and efficient road management program. The multi-criteria analysis that was based on the Directorate General Bina Marga 2015-2019 strategic plan program could result in the suggestion for national road management necessity for South Sumatra Province in 2015-2019, which are as follows:

a) Maintenance needs in 2015 including (1) routine maintenance of $95.86 \%$ consists of $48.11 \%$ minor routine, $19.51 \%$ routine condition, and $30.22 \%$ routine preventive, (2) periodical maintenance $2.61 \%$, (3) structure enhancement $1.53 \%$, consists of $0.55 \%$ major rehabilitation, and $0.99 \%$ reconstruction, and (4) capacity enhancement of $12.13 \%$, consists of $9.87 \%$ of 7.00 meter widening, and $2.26 \%$ of 14.00 meter widening.

b) Maintenance needs in 2016 including (1) routine maintenance of $99.996 \%$ consists of $64.17 \%$ minor routine, $0.23 \%$ routine condition, and $5.6 \%$ routine preventive, (2) periodical maintenance $0.004 \%$, (3) capacity enhancement of $9.84 \%$, consists of $9.41 \%$ of 7.00 meter widening, and $0.43 \%$ of 14.00 meter widening.

c) Maintenance needs in 2017 including (1) routine maintenance of $99.996 \%$ consist of $61.59 \%$ minor routine, $28.20 \%$ routine condition, and $10.20 \%$ routine preventive, (2) periodical maintenance $0.004 \%$, (3) capacity enhancement of $6.96 \%$ with7.00 meter widening.

d) Maintenance needs in 2018 including (1) routine maintenance of $99.998 \%$ consist of $63,67 \%$ minor routine, $31.06 \%$ routine condition, and $8.93 \%$ routine preventive, (2) periodical maintenance $0.002 \%$.

e) Maintenance needs in 2019 including (1) routine maintenance of $99.998 \%$ consist of $68.23 \%$ minor routine, $22.50 \%$ routine condition, and $9.29 \%$ routine preventive, (2) periodical maintenance $0.002 \%$.

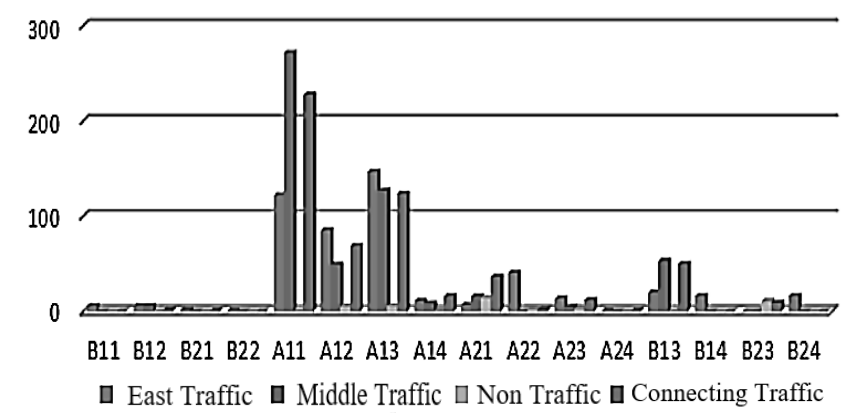

Figure 3. National road management program in South Sumatra Province (2015). 


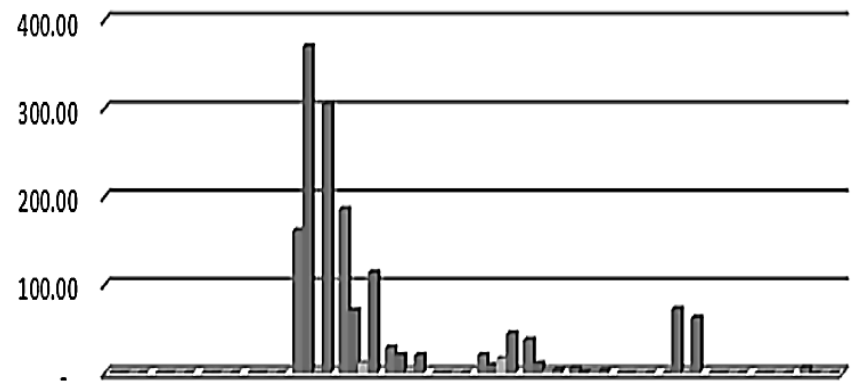

B11 B12 B21 B22 A11 A12 A13 A14 A21 A22 A23 A24 B13 B14 B23 B24

$\square$ East Traffic $\square$ Middle Traffic $\square$ Non Traffic $\square$ Connecting Traffic

Figure 4. National Road Management Program in South Sumatra Province (2016)

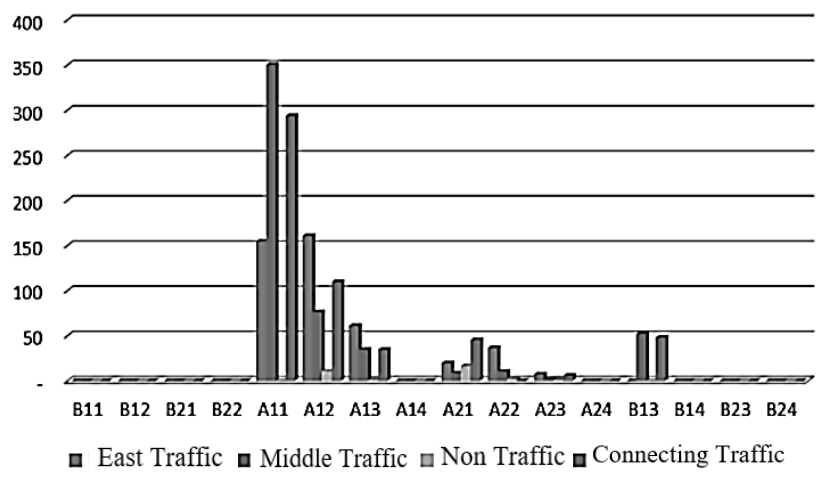

Figure 5. National Road Management Program in South Sumatra Province (2017)

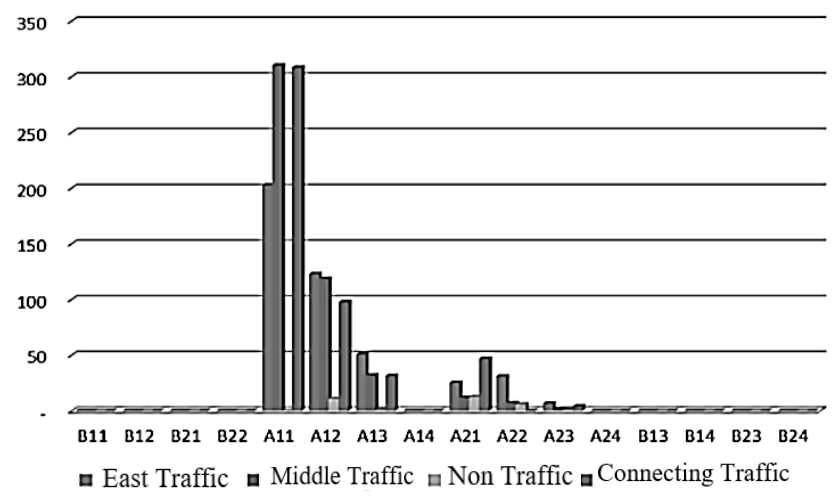

Figure 6. National Road Management Program in South Sumatra Province (2018)

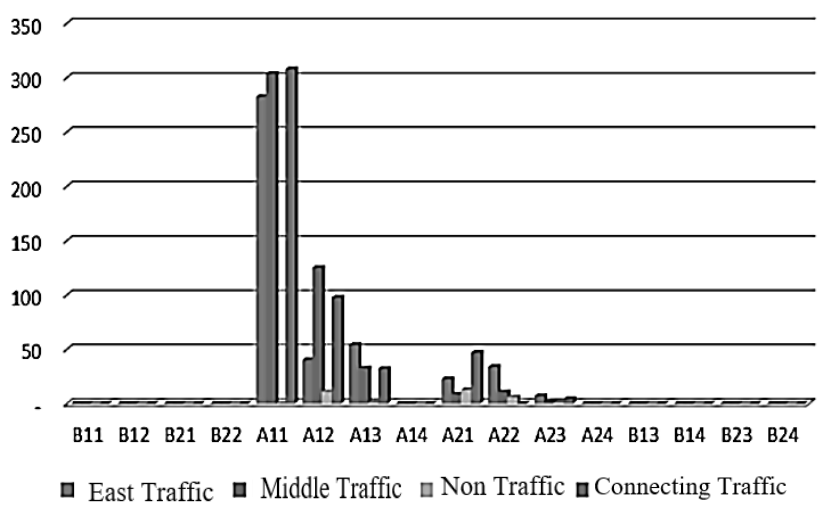

Figure 7. National Road Management Program in South Sumatra Province (2019)

\subsection{Prediction on National Road Network Condition (2015-2019)}

The analysis result of national road modernization in 2015-2019 based on the condition of national road width showed that $990.34 \mathrm{~km}$ (almost 90\%) have 6.07.0 meter width, which means that almost $90 \%$ of the national road in South Sumatra are heading toward the medium road class. This width condition has not reached the target of Directorate General Bina Marga strategic plan, which is the national road width in 2019 of 7.0 meter at least. The change in width condition of national road in 2015-2019 is shown in Figure 8 . The analysis result of traffic volume showed that $1,316.42 \mathrm{~km}(91.13 \%)$ of national road in South Sumatra has traffic volume of $\geq 12,000 \mathrm{pcu} /$ day on year 2019, as seen in Figure 9. This traffic volume was much lower when compared to the requirement for medium road ( $\leq 22,000 \mathrm{pcu} /$ day $)$, therefore the road width of 7.0 meter is already adequate. The analysis result on the national road performance condition in South Sumatra in 2019 is: (a) $614.79 \mathrm{~km}$ has V/C ratio of $0.3-0.5$, as seen in Figure 10, (b) $1,159.29 \mathrm{~km}$ has travel speed of $\leq 50 \mathrm{~km} /$ hour, as seen in Figure 11, (c) $624.86 \mathrm{~km}$ has travel speed of 1.8-2.0 hour/100km, as seen in Figure 12, (d) 1,444.26 km has stability level of $\geq 95 \%$, as seen in Figure 13, (e) $1,311.73 \mathrm{~km}$ has IRI value of $<4$, as seen in Figure 14, (f) $1,444.26 \mathrm{~km}$ has SDI value of $<50$, as seen in Figure 15 . 


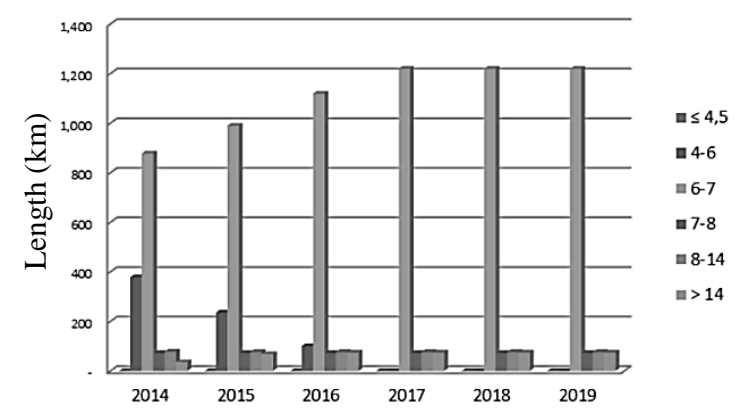

Figure 8. Road length based on width in South Sumatra (2014-2019).

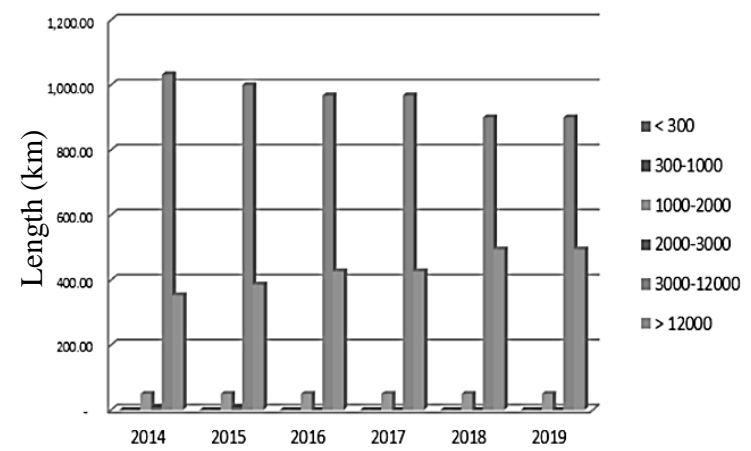

Figure 9. Road length based on V/C ratio value in South Sumatra (2014 -2019).

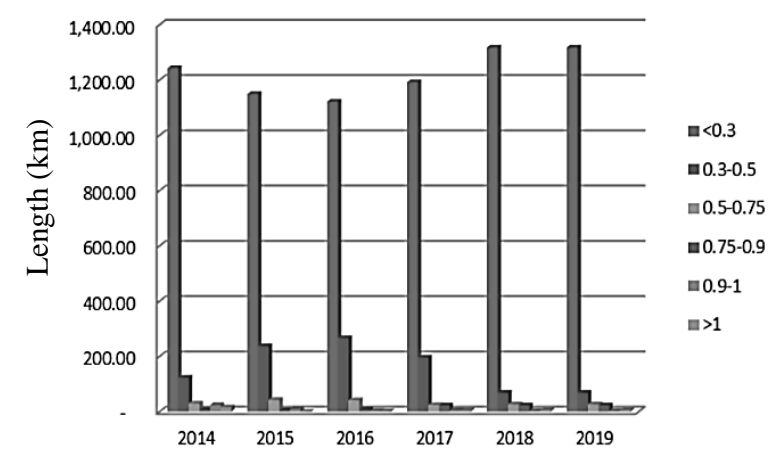

Figure 10. Road length based on V/C ratio value in South Sumatra (2014 -2019).

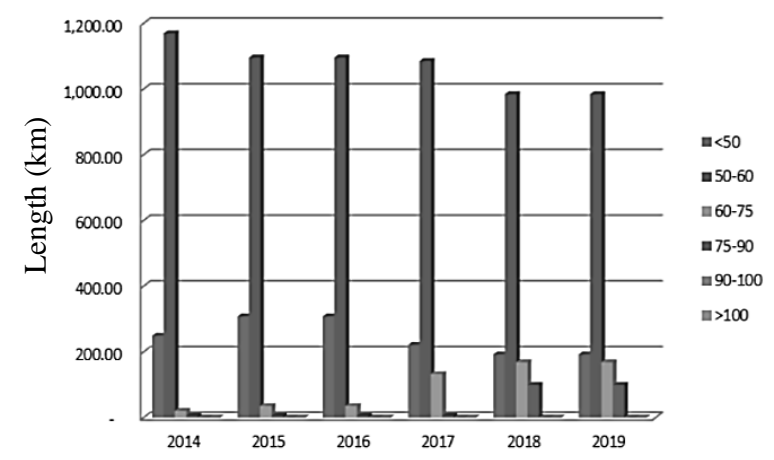

Figure 11. Road length based on speed in South Sumatra (2014-2019).

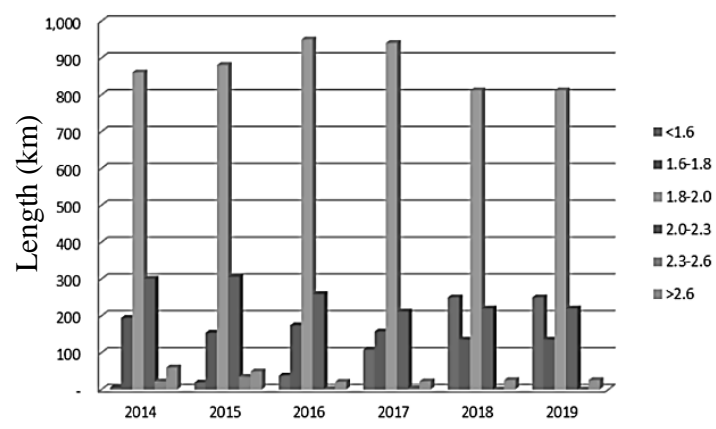

Figure 12. Road length based on travel time in South Sumatra (2014-2019).

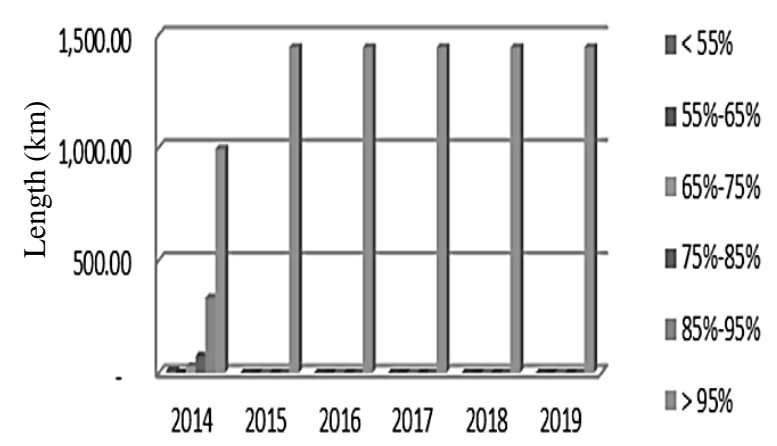

Figure 13. Road length based on stability level in South Sumatra (2014 -2019).

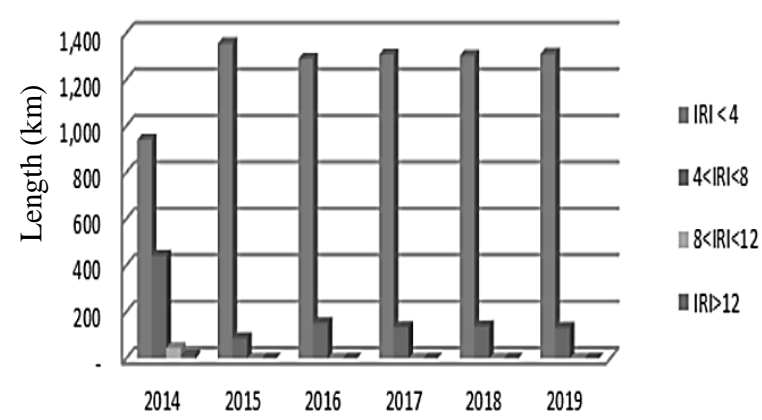

Figure 14. Road length based on IRI value in South Sumatra (2014 -2019).

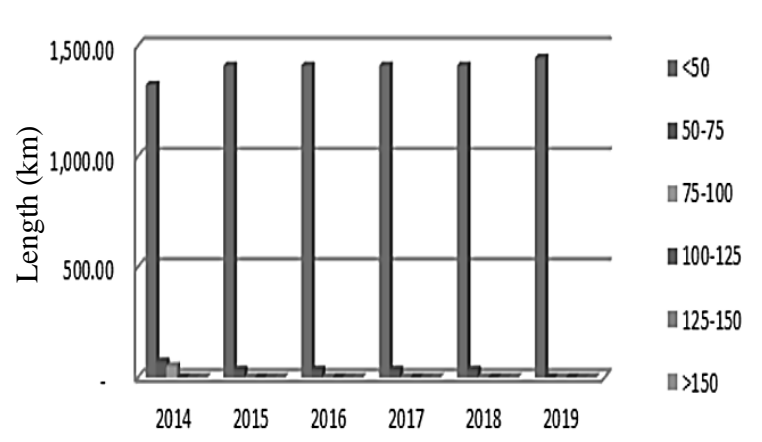

Figure 15. Road length based on SDI in South Sumatra (2014 -2019). 


\subsection{Target on National Road Network Stability and} Performance Achievement

The result from transportation modeling in the form of significant road length achievement of South Sumatra National Road based on the Directorate General Bina Marga 2015-2019 strategic plan program target could be seen in Table 2. The target of the road length that undergo road widening to 7.0 meter (medium road) is $100 \%$ fulfilled (2019) and increased from $73.76 \%$ (2014).

This condition is quite optimal because $97.83 \%$ of the road length has achieved V/C ratio $<0.75$ (2019), although the increase was not significant from the $96.67 \%$ in 2014 . The achievement target of the national road length based on travel speed $<1.5$ hour/100 km was still low, of 17.32 (2019), even though there were already significantly increased from $0.39 \%$ (2014). The achievement target the national road length based on IRI was $<4,0 \mathrm{~m} / \mathrm{km}$, has increased from $56.66 \%$ (2014) to $90.37 \%$ (2019), as well as the national road based on SDI <50, from $86.53 \%$ (2014) up to $97.65 \%$ (2019).

The research result showed an antagonistic condition, for the road width of 7.0 meter with IRI value of $<4.0$ $\mathrm{m} / \mathrm{km}$ has already fulfilled almost $100 \%$ (2019), yet unable to service vehicle traffic with speed more than $60 \mathrm{~km} /$ hour and travel time was way above 1.5 hour $/ 100 \mathrm{~km}$. This was due to the absence of national road modernization program that has substandard geometrical road improvement program.

Table 2. Achievement target of national road length in South Sumatra Province based on direction of Strategic Plan of Directorate General Bina Marga 2015-2019 (\%)

\begin{tabular}{|c|c|c|c|c|c|c|c|c|c|c|c|}
\hline \multirow[t]{2}{*}{ Condition } & \multirow{2}{*}{2014} & \multicolumn{2}{|l|}{2015} & \multicolumn{2}{|l|}{2016} & \multicolumn{2}{|l|}{2017} & \multicolumn{2}{|l|}{2018} & \multicolumn{2}{|l|}{2019} \\
\hline & & DN & DS & DN & DS & DN & DS & DN & DS & DN & DS \\
\hline \multicolumn{12}{|l|}{ East Corridor: } \\
\hline Road width> 7.0 meter & 29.12 & 29.12 & 30.52 & 29.12 & 30.52 & 29.12 & 30.52 & 29.12 & 30.52 & 29.12 & 30.52 \\
\hline $\mathrm{V} / \mathrm{C}$ ratio $<0.75$ & 27.24 & 27.24 & 29.50 & 26.89 & 29.58 & 25.70 & 28.39 & 25.70 & 28.39 & 25.70 & 28.39 \\
\hline $\mathrm{V}$ speed $>60 \mathrm{~km} /$ hour & 0.43 & 0.43 & 1.37 & 0.43 & 1.37 & 0.39 & 6.55 & 0.39 & 12.99 & 0.39 & 12.99 \\
\hline TT $<1.6$ hour per $100 \mathrm{~km}$ & 0.39 & 0.39 & 1.32 & 0.39 & 2.62 & 0.39 & 6.51 & 0.39 & 12.99 & 0.39 & 12.99 \\
\hline IRI $<4.0 \mathrm{~m} / \mathrm{km}$ & 17.63 & 13.67 & 28.11 & 10.44 & 25.76 & 7.60 & 26.52 & 5.35 & 26.28 & 4.05 & 26.36 \\
\hline $\mathrm{SDI}<50$ & 23.09 & 21.70 & 28.17 & 21.48 & 28.17 & 15.00 & 28.17 & 15.00 & 28.17 & 15.00 & 30.52 \\
\hline \multicolumn{12}{|l|}{ Middle Corridor: } \\
\hline Road width $>7.0$ meter & 21.04 & 21.04 & 24.70 & 21.04 & 29.76 & 21.04 & 33.37 & 21.04 & 33.37 & 21.04 & 33.37 \\
\hline $\mathrm{V} / \mathrm{C}$ ratio $<0.75$ & 33.37 & 33.37 & 33.37 & 33.37 & 33.37 & 33.37 & 33.37 & 33.37 & 33.37 & 33.37 & 33.37 \\
\hline$V$ speed $>60 \mathrm{~km} /$ hour & 0.63 & 0.63 & 0.63 & 0.63 & 0.63 & 0.63 & 0.63 & 0.63 & 0.63 & 0.63 & 0.63 \\
\hline TT $<1.6$ hour per $100 \mathrm{~km}$ & 0.00 & 0.00 & 0.00 & 0.00 & 0.00 & 0.00 & 0.00 & 0.00 & 0.00 & 0.00 & 0.00 \\
\hline IRI $<4.0 \mathrm{~m} / \mathrm{km}$ & 23.29 & 21.16 & 31.87 & 19.29 & 30.88 & 17.54 & 31.07 & 15.91 & 31.03 & 14.37 & 31.04 \\
\hline $\mathrm{SDI}<50$ & 33.31 & 29.65 & 33.37 & 29.31 & 33.37 & 29.31 & 33.37 & 29.31 & 33.37 & 28.81 & 33.37 \\
\hline \multicolumn{12}{|l|}{ Non Corridor:: } \\
\hline Road width $>7.0$ meter & 1.45 & 1.45 & 2.20 & 1.45 & 2.20 & 1.45 & 2.20 & 1.45 & 2.20 & 1.45 & 2.20 \\
\hline $\mathrm{V} / \mathrm{C}$ ratio $<0.75$ & 2.15 & 2.20 & 2.20 & 2.20 & 2.20 & 2.15 & 2.20 & 2.15 & 2.15 & 2.15 & 2.15 \\
\hline$V$ speed $>60 \mathrm{~km} /$ hour & 0.27 & 0.27 & 0.27 & 0.27 & 0.27 & 0.27 & 0.82 & 0.00 & 0.35 & 0.00 & 0.35 \\
\hline TT $<1.6$ hour per $100 \mathrm{~km}$ & 0.00 & 0.00 & 0.00 & 0.00 & 0.00 & 0.00 & 0.00 & 0.00 & 0.35 & 0.00 & 0.35 \\
\hline IRI $<4.0 \mathrm{~m} / \mathrm{km}$ & 1.52 & 1.40 & 2.12 & 1.30 & 2.06 & 1.20 & 2.07 & 1.10 & 2.07 & 1.02 & 2.07 \\
\hline $\mathrm{SDI}<50$ & 2.20 & 2.20 & 2.20 & 2.20 & 2.20 & 2.20 & 2.20 & 2.20 & 2.20 & 2.20 & 2.20 \\
\hline
\end{tabular}


Table 2. Achievement target of national road length in South Sumatra Province based on direction of Strategic Plan of Directorate General Bina Marga 2015-2019 (\%) (continued)

\begin{tabular}{lllllllllllll}
\hline Condition & 2014 & 2015 & & 2016 & & 2017 & & 2018 & & 2019 \\
& & DN & DS & DN & DS & DN & DS & DN & DS & DN & DS \\
\hline Connecting link : & & & & & & & & & & & \\
\hline Road width > 7.0 meter & 22.15 & 22.15 & 26.21 & 22.15 & 30.56 & 22.15 & 33.91 & 22.15 & 33.91 & 22.15 & 33.91 \\
V/C ratio < 0.75 & 33.91 & 33.91 & 33.91 & 33.91 & 33.91 & 33.91 & 33.91 & 33.91 & 33.91 & 33.91 & 33.91 \\
V speed > 60 km/ hour & 0.46 & 0.55 & 0.55 & 0.46 & 0.55 & 0.55 & 1.54 & 0.55 & 4.54 & 0.55 & 4.54 \\
TT < 1.6 hour per 100 km & 0.00 & 0.00 & 0.00 & 0.00 & 0.00 & 0.00 & 0.99 & 0.00 & 3.99 & 0.00 & 3.99 \\
IRI < 4.0 m/km & 22.76 & 20.42 & 31.83 & 18.48 & 30.68 & 16.82 & 30.98 & 15.29 & 30.91 & 13.91 & 30.90 \\
SDI < 50 & 32.99 & 32.99 & 33.91 & 32.06 & 33.91 & 29.12 & 33.91 & 29.12 & 33.91 & 29.12 & 33.91 \\
South Sumatra Province: & & & & & & & & & & & \\
Road width > 7.0 meter & 73.76 & 73.76 & 83.63 & 73.76 & 93.04 & 73.76 & 100.00 & 73.76 & 100.00 & 73.76 & 100.00 \\
V/C ratio < 0.75 & 96.67 & 96.67 & 98.98 & 96.37 & 99.06 & 95.14 & 97.83 & 95.14 & 97.83 & 95.14 & 97.83 \\
V speed > 60 km/ hour & 1.79 & 1.88 & 2.82 & 1.79 & 2.82 & 1.84 & 9.53 & 1.56 & 18.50 & 1.56 & 18.50 \\
TT < 1.6 hour per 100 km & 0.39 & 0.39 & 1.32 & 0.39 & 2.62 & 0.39 & 7.49 & 0.39 & 17.32 & 0.39 & 17.32 \\
IRI < 4.0 m/km & 65.20 & 56.66 & 93.92 & 49.51 & 89.38 & 43.16 & 90.64 & 37.66 & 90.29 & 33.35 & 90.37 \\
SDI < 50 & 91.59 & 86.53 & 97.65 & 85.05 & 97.65 & 75.63 & 97.65 & 75.63 & 97.65 & 75.13 & 97.65 \\
\hline
\end{tabular}

Note: DN = Do Nothing;

DS = Do Something

\section{CONCLUSIONS AND SUGGESTIONS}

\subsection{Conclusions}

The multi-criteria analysis combined the rating score of the road technical condition with the level interest rank of the area development that traversed by the road network. Several conclusions obtained are as follows:

a) Maintenance needs in 2015 including (1) routine maintenance of $95.86 \%$ consists of $48.11 \%$ minor routine, $19.51 \%$ routine condition, and $30.22 \%$ routine preventive, (2) periodical maintenance $2.61 \%$, (3) structure enhancement $1.53 \%$, consists of $0,55 \%$ major rehabilitation, and $0.99 \%$ reconstruction, and (4) capacity enhancement of $12.13 \%$, consists of $9.87 \%$ of 7.00 meter widening, and $2.26 \%$ of 14.00 meter widening.

b) Maintenance needs in 2016 including(1) routine maintenance of $99.99 \%$ consist of $64.17 \%$ minor routine, $30.23 \%$ routine condition, and $5.6 \%$ routine preventive, (2) capacity enhancement of $9.84 \%$, consists of $9.41 \%$ of 7.00 meter widening, and $0.43 \%$ of 14.00 meter widening.

c) Maintenance needs in 2017 including (1) routine maintenance of $99.99 \%$ consist of $61.59 \%$ minor routine, $28.20 \%$ routine condition, and $10.20 \%$ routine preventive, (2) capacity enhancement of $6.96 \%$ with 7.00 meter widening. d) Maintenance needs in 2018 including (1) routine maintenance of $99.99 \%$ consists of $63.67 \%$ minor routine, $31.06 \%$ routine condition, and $8.93 \%$ routine preventive.

e) Maintenance needs in 2019 including (1) routine maintenance of $99.99 \%$ consists of $68.23 \%$ minor routine, $22.50 \%$ routine condition, and $9.29 \%$ routine preventive.

The suggestion for the national road management necessity (2015-1019) has a significant effect on the service performance improvement as follows:

a) The target for road length widening was achieved to $7.0 \mathrm{~m}$ (medium road), $100 \%$ fulfilled in 2019 , and increased from $73.76 \%$ in 2014. This condition is quite optimal because $97.83 \%$ of the road length has achieved V/C ratio < 0.75 (2019), although the increase was not significant from the $96.67 \%$ in 2014.

b) Achievement target for national road length that has travel speed of $>60 \mathrm{~km} /$ hour (arterial road function) was still too low in 2019 , although there were already significantly increased from $1.88 \%$ in 2014.

c) Achievement target of the national road length based on travel speed $<1.5$ hour $/ 100 \mathrm{~km}$ was still low (2019), even though there were already significantly increased from $0.39 \%$ (2014).

d) The achievement target the national road length with IRI value of $<4.0 \mathrm{~m} / \mathrm{km}$ increased from 
$56.66 \%$ (2014) to $90.37 \%$ (2019), as well as the national road with SDI <50, from $86.53 \%$ (2014) up to $97.65 \%$ (2019). For achievement of $100 \%$ (2019), road length that undergoes widening to 7 meters and with IRI value of $<4.0 \mathrm{~m} / \mathrm{km}$ apparently did not affect the road length enhancement which has the travel time of $<1.5$ hour $/ 100 \mathrm{~km}$. This was caused due to the absence of the suggestion on the special management program for improvement on the geometrically substandard road.

\subsection{Suggestions}

Development for further road network management program necessity should consider:

a) Coordination with stakeholder on the policy of handling the unideal traffic.

b) Analysis on the road by per segment, in order to produce a more detailed management suggestion.

c) Program suggestion with management type of fly over, under pass, or bypass, as the improvement solution to the unideal road performance (traffic).

\section{REFERENCES}

Ardhiarini, R., 2015. Identifikasi Kebutuhan Penanganan Jalan Nasional Berdasarkan Arahan Renstra Ditjen Bina Marga (2015-2019) [Identification of the Needs of National Road Implementation based on Strategic Plan of Directorate General of Bina Marga 2015-2019], Yogyakarta: Master Thesis, Departement of Civil and Environmental Engineering, Universitas Gadjah Mada.

DfCLG, 2009. Multi-criteria Analysis: A Manual, London: Department for Communities and Local Government (DfCLG).

Directorate General of Bina Marga, 2014. Rencana Strategis Ditjen Bina Marga 2015-2019 [Strategic Plan of Directorate General of Bina Marga 20152019], Jakarta: Ditjen Bina Marga.

Government of Indonesia, 2004. Republic of Indonesia Laws No. 38 Year 2004 on Road, Jakarta: Government of Indonesia.

Government of Indonesia, 2006. Government Laws No. 34 Year 2006 on Road, Jakarta: Government of Indonesia.
Government of Indonesia, 2008. Government Laws No. 26 Year 2008 on National Spatial Planning, Jakarta: Government of Indonesia.

IndII, 2012. Menuju Jaringan Jalan Nasional yang Modern: Penetapan Kerangka Perencanaan untuk Peningkatan Konektivitas dan Keseimbangan Pembangunan [Heading to Modern National Road Network: Determination of Planning Scheme for Enhancing Connectivity]. Jakarta: Australian AID.

Koesno, S. \& Marbun, J., 1995. Penyempurnaan dan Pengembangan IRMS Dalam Mengantisipasi Pembinaan Jaringan Jalan pada PJP II [Accomplishment and Development of IRMS in Management of Road Network PJP II]. Makalah Teknik Desain dan Pelaksanaan KRTJ-4, 3(1), pp. 523.

Maulidya, M., 2014. Prioritas Penanganan Jalan Nasional Berdasarkan Metode Analisis Multi Kriteria (Studi Kasus di Kota Banda Aceh) [Priority of the Implementation of National Road Network based on Multi Analysis Criteria], Banda Aceh: Thesis Report, Universitas Syiah Kuala.

Mulyono, A., 2014. Perubahan Paradigma Penyelenggaraan Infrastruktur Jalan dan Jembatan [Changes of Paradigma in Infrastructure Implementation], Jakarta: Rumah Transisi Joko Widodo-Jusuf Kalla.

Pickford, M., 2013. State Highway Investment in New Zealand: The Decline and Fall of Economic Efficiency, Policy Quarterly. 9(3), pp. 28-35.

Sepang, P. \& Mouradhy, P., 1995. Peningkatan Muatan Sumbu Kendaraan Truk (axle load) di Lintas Timur Sumatera yang Perlu Diwaspadai dan Ditanggulangi [The Increase of Truck Axle Load in Sumatra Road]. Padang, Prosiding Konferensi Regional Teknik Jalan ke-4.

Sulistyorini, R. \& Herianto, D., 2010. Analisis Multi Kriteria Sebagai Metode Pemilihan Suatu Alternatif Ruas Jalan di Provinsi Lampung [Analysis of Multi Criteria as Determination Method for Alternative Road in Lampung Province]. Jurnal Rekayasa, 14(3). 
[this page intentionally left blank] 